\title{
GROUND PENETRATING RADAR DATA ANALYSIS BY USING MODELLING WITH FINITE DIFFERENCE METHOD: CASE STUDY IN BELAWAN PORT
}

\section{ANALISIS DATA GROUND PENETRATING RADAR MENGGUNAKAN PEMODELAN DENGAN METODE FINITE DIFFERENCE: STUDI KASUS DERMAGA BELAWAN}

\author{
Hans Elmaury Andreas Siregar \\ Centre for Geological Resources \\ Jalan Soekarno Hatta No.444 Bandung \\ hans.elmauri@gmail.com
}

\begin{abstract}
Ground Penetrating Radar (GPR) is one of non destructive geophysics methods which is appropriate used to identify subsurface object with depth penetration less than 70 meter. High data resolution as well as relatively unprolonged and manageable data acquisition make this method becoming convenient supporting method to increase near surface data for other geophysics methods. The depth penetration of GPR varies with the frequency of antenna. Getting optimum depth penetration before field acquisition data some numerical simulation should be accomplished in order to perceive antenna frequency and processing technique that used, so the depth of target zone can be achieved. The Finite Difference (FD) is one of numerical anaysis technique that mostly used to determine differential equation. By using FD method, the solution of electromagnetic waves equation can be obtained and the image of numerical simulation can be displayed. In line with this radar image from numerical simulation, the relationship of frequency and depth penetration on the media used is acquired. Media used in this simulation are sand, clay, sandy clay, clayey sand and concrete. Through numerical simulation from this research, we conclude that GPR method able to distinguish boundary layer among each medium. Processing technique is accomplished to comprehend suitable processing stages for high resolution radar image that can be interpreted. Data acquisition and processing technique from simulation have been implemented in field experiment and very helpful to apprehend GPR characteristic signal in subsurface map in Belawan port.
\end{abstract}

Keywords: Ground Penetrating Radar, numerical simulation, finite difference, processing technique.

\section{ABSTRAK}

Ground Penetrating Radar (GPR) adalah salah satu metode geofisika non-destruktif yang dapat digunakan untuk mengidentifikasi bawah permukaan dengan penetrasi kurang dari 70 meter. Data resolusi tinggi dengan akuisisi yang tidak lama dan relatif sederhana membuat metode ini sangat sesuai sebagai pendukung untuk metode geofisika yang lain dalam pendataan bawah permukaan yang tidak dalam. Penetrasi kedalaman GPR akan snagat tergantung dari frekuensi antena yang digunakan. Untuk mendapatkan penetrasi kedalaman yang optimum, maka perlu dilakukan simulasi numerik sebelum pendataan lapangan dilakukan untuk mendapatkan frekuensi antena dan teknik pemrosesan yang tepat sesuai dengan target kedalaman yang ingin dicapai. Metode Finite Difference adalah salah satu teknik analisis dalam menentukan persamaan diferensial. Dengan metode FD ini akan didapat persamaan gelombang elektromagnetik dan gambaran dari citra simulasi numeriknya. Sejalan dengan citra radar dari simulasi numerik, akan didapat hubungan antara frekuensi dan penetrasi kedalaman dari media/material bawah permukaan. Media yang dipakai dalam simulasi ini berupa pasir, lempung, lempung pasiran, pasir lempungan 


\section{MAKALAH ILMIAH}

dan beton. Dari hasil simulasi numerik dapat disimpulkan bahwa metode GPR ini dapat membedakan batas lapisan setiap media. Teknik pemrosesan dilakukan untuk mendukung interpretasi citra radar beresolusi tinggi. Akuisisi data dan teknik pemrosesan dari simulasi ini telah diimplementasikan dalam percobaan di lapangan dan sangat membantu dalam menganalisis karakteristik signal GPR dalam peta bawah permukaan di Pelabuhan Belawan.

Kata kunci: Ground Penetrating Radar, simulasi numerik, finite difference, teknik pemrosesan

\section{INTRODUCTION}

In understanding the working principle of electromagnetic waves, the first thing that need to know is the four Maxwell's Equations. These Maxwell's equations describe the physical relationships in electromagnetic waves. The four equations are:

$\vec{\nabla} \times \overrightarrow{\mathrm{E}}=-\frac{\partial \overrightarrow{\mathrm{B}}}{\partial \mathrm{t}}$
$\vec{\nabla} \times \overrightarrow{\mathrm{H}}=\overrightarrow{\mathrm{J}}+\frac{\partial \overrightarrow{\mathrm{D}}}{\partial \mathrm{t}}$
$\vec{\nabla} \cdot \overrightarrow{\mathrm{D}}=\mathrm{q}$
$\vec{\nabla} \cdot \overrightarrow{\mathrm{B}}=0$

where:

$\overline{\mathrm{E}}=$ Electric field $(\mathrm{V} / \mathrm{m})$

$\overline{\mathrm{H}}=$ Magnetic field $(\mathrm{A} / \mathrm{m})$

$\overline{\mathrm{B}}=$ Magnetic induction $\left(\mathrm{Vs} / \mathrm{m}^{2}\right)$

$\overline{\mathrm{D}}=$ Electric displacement $\left(\mathrm{As} / \mathrm{m}^{2}\right)$

$\bar{J}=$ Current density $\left(\mathrm{A} / \mathrm{m}^{2}\right)$

$\mathrm{q}=$ Charge density $\left(\mathrm{As} / \mathrm{m}^{3}\right)$

The equations above generally show the relationship between the magnetic field and the electric field. Moreover, the equation shows that the current flow microstructure in a space can generate a magnetic field with a linear comparison.

Constitutive equation is an equation which links Maxwell's equations and inhomogeneous earth medium. Constitutive equation quantifies material physical parameters and explains the influence of the electromagnetic field's presence on the electron/atom or even ion. The equations are:

$\vec{J}=\sigma \vec{E}$
$\vec{D}=\varepsilon \vec{E}=\varepsilon_{r} \varepsilon_{o} \vec{E}$
$\vec{B}=\mu \vec{H}=\mu_{r} \mu_{o} \vec{H}$
(Baker and Harry, 2007)

where:

$\sigma=$ Conductivity (Siemens $/ \mathrm{m}$ )

$\varepsilon=$ Medium permittivity (Farad $/ \mathrm{m}) ;$

$$
\varepsilon=\varepsilon_{r} \varepsilon_{o}
$$

$\varepsilon_{\mathrm{r}}=$ Relative medium permittivity

$\varepsilon_{\mathrm{o}}=$ Permittivity in a vacuum chamber $=$ $8.85 \times 10^{-12}$ (Farad $\left./ \mathrm{m}\right)$

$\mu=$ Magnetic permeability of the medium (Henry/m);

$$
\mu=\mu_{r} \mu_{0}
$$

$\mu_{\mathrm{r}}=$ Relative magnetic permeability of the medium

$\mu_{\mathrm{o}}=$ Magnetic permeability of the vacuum chamber $=4 \pi \times 10^{-7}$ (Henry $\left./ \mathrm{m}\right)$

The recovering of radar image is a forward modelling. In this study, the data input is the electromagnetic impedance or reflection coefficient (RC) series of the medium itself which then forward modelled into raw radar image.

The numerical simulation involves representing a simulated system by a mathematical model. Type of model used normally depends on parameter such as the required accuracy, the total simulation time, the type of results required, the frequency bandwith, and so on (Buchanan, 1996). The finite difference method provides a direct soution to Maxwell's equation with little complexity. In formulation, Maxwell's continuous equations are converted into a discrete form (Buchanan, 1996). The software then solves this discrete form and creates raw radar image. Buchanan (1996) stated that the advantage over other methods that it takes into account all fields (electric and magnetic) in a 2D model and is well suited to parallel processing. Comparatively study between processing result and 
synthetic model leads us into understanding of processing stages.

The purpose of modeling in this study are (modification from Annan, 2003):

1. To understand physical behavior and quantiying response

2. Providing performance requirements for design of GPR tool

3. Predicting response and sensitivity to parameter changes

4. Optimizing survey design

5. Understanding how to process data to extract information

6. Enabling interpretation at a variety of levels of complexity

Hopefully this study can be a preliminary study before conducting GPR data acquisition in the field.

\section{METHODS}

Method that used in high frequency electromagnetic wave simulations is the one that take into account changes in the physical and dielectric structure. This study simply used finite difference as numerical simulation method. The software used to generate the model in this simulation is reflexW.

The first step is model generation. Figure 1 is the synthetic model based on various dielectric value of the medium. The model itself has the limitation in space due to computer limitation in storing the data. The boundary condition is applied from the software to attenuate or absorb the wave energy must be used.

The next step is simulation by using finite difference. It involves steping the model through discrete interval. It models the propagation through the element using a discrete form of Maxwell's curl equation (Buchanan, 1996). With the option raster activated first the chosen model will be rastered based on the current parameter and the finite difference computation will be started (Sandmeier, 1998). The computation is started immediately using the current raster values stored in the different rasterfiles (Sandmeier, 1998). The program automatically controls if the size of the rasterfiles matches the currently set values of the raster increment and the model size (Sandmeier, 1998). The result of this calculation is wave field depending on $\mathrm{x}, \mathrm{z}$, and $\mathrm{t}$ (time) and the parameters are stored in the ASCll-file (Sandmeier, 1998). Figure 2 shows the result of finite difference simulation.

The last step is data processing technique. Figure 5 shows the processing stages conducting in this study. The synthetic model is used as the validation in data processing.

\section{SYNTHETIC MODEL}

Based on preliminary study in the location of field experiment, there are some shallow well data. From the well data, this area is underlain by five media (Table 1). In line with that information, synthetic model was generated with ReflexW software. The data from each medium are developed from various laboratory test in some textbooks. The wave type that used is electromagnetic wave. The model is generated with reflexW software. Each layer in this model is created with certain dimension and parameters (Figure 1). Those parameters are simulated with FD method. The finite difference modeling in time domain allows the simulation of electromagnetic by means of FD method for different sources (plane wave, point source as well as exploding reflector source (Sandmeier, 1998). Exploding reflector source is used in this simulation with frequency $150 \mathrm{MHz}$. As a result, a raw data in .dat file can be displayed (Figure 2). The raw data is processed with certain processing technique to obtain robust image. The image, as the forward modeling result, will be compared with the synthetic model in order to meet appropriate processing technique. 


\section{MAKALAH ILMIAH}

When simulation accomplished, raw data were obtained in dat format (Figure 2). Then the data proccessing was conducted using the software. In the data processing, frequency filtering of the data was attained in order to obtain the appropriate data to the target frequency and noise removal was accomplished to clean up the data from the signals that were not expected and signal amplification was conducted to clarify the signal to be easily read and interpreted.

Table 1. Dielectric properties of common geological material used in this simulation (modification from McCann et al., 1988).

\begin{tabular}{lrr}
\hline \multicolumn{1}{c}{ Medium } & Permittivity (F/m) & Conductivity $\mathbf{( S / m )}$ \\
\hline Concrete & 10 & 0,034 \\
\hline Sand & 30 & 0,005 \\
\hline Clay & 3 & 0,0001 \\
\hline Clayey sand & 5 & 0,0005 \\
\hline Sandy clay & 20 & 0,001 \\
\hline
\end{tabular}

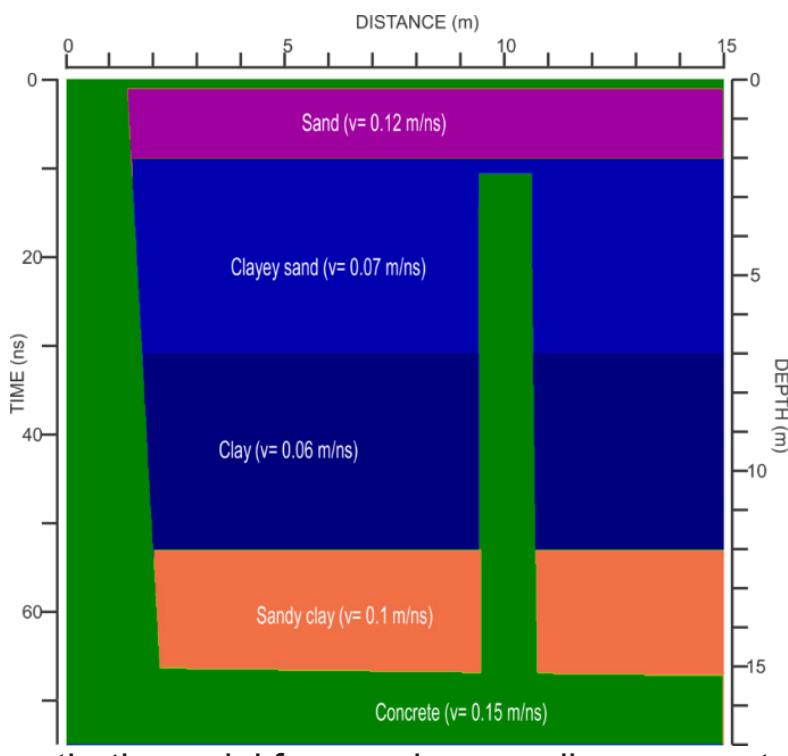

Figure 1. The synthetic model from various medium generated from different electromagnetic velocity (Siregar, 2012).

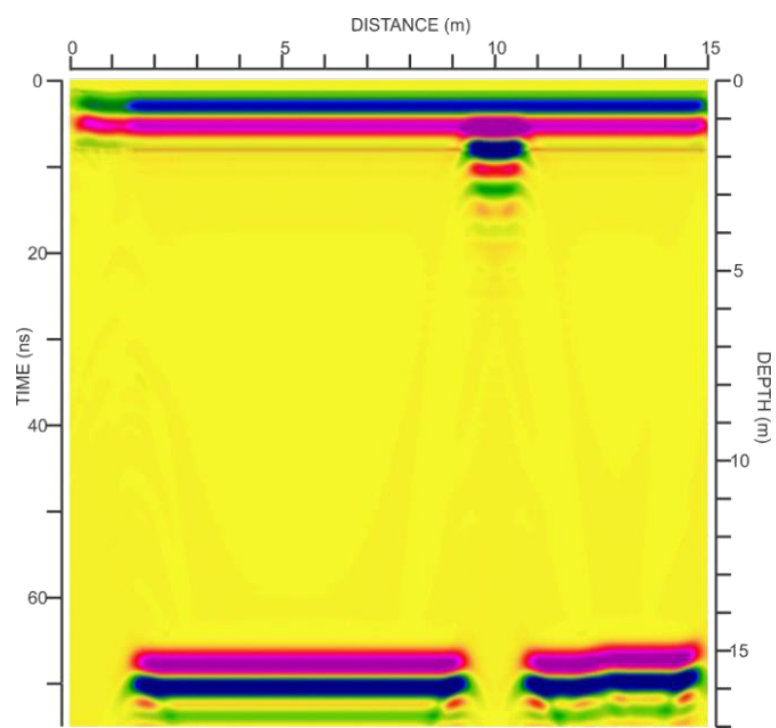

Figure 2. Raw data from the FD simulation result in dat format (Siregar, 2012). 


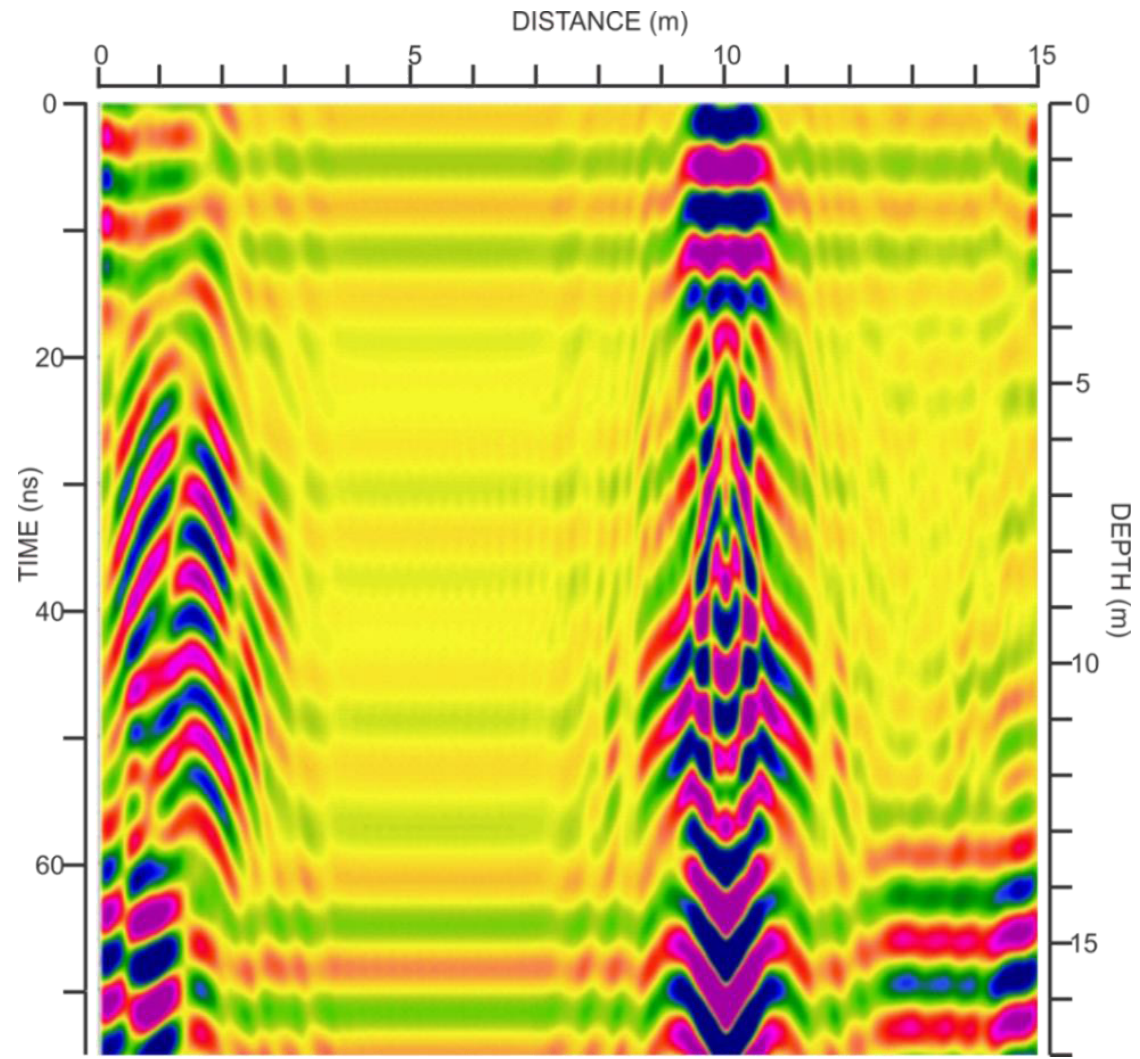

Figure 3. The radar image after processed by using several stages (Siregar, 2012).

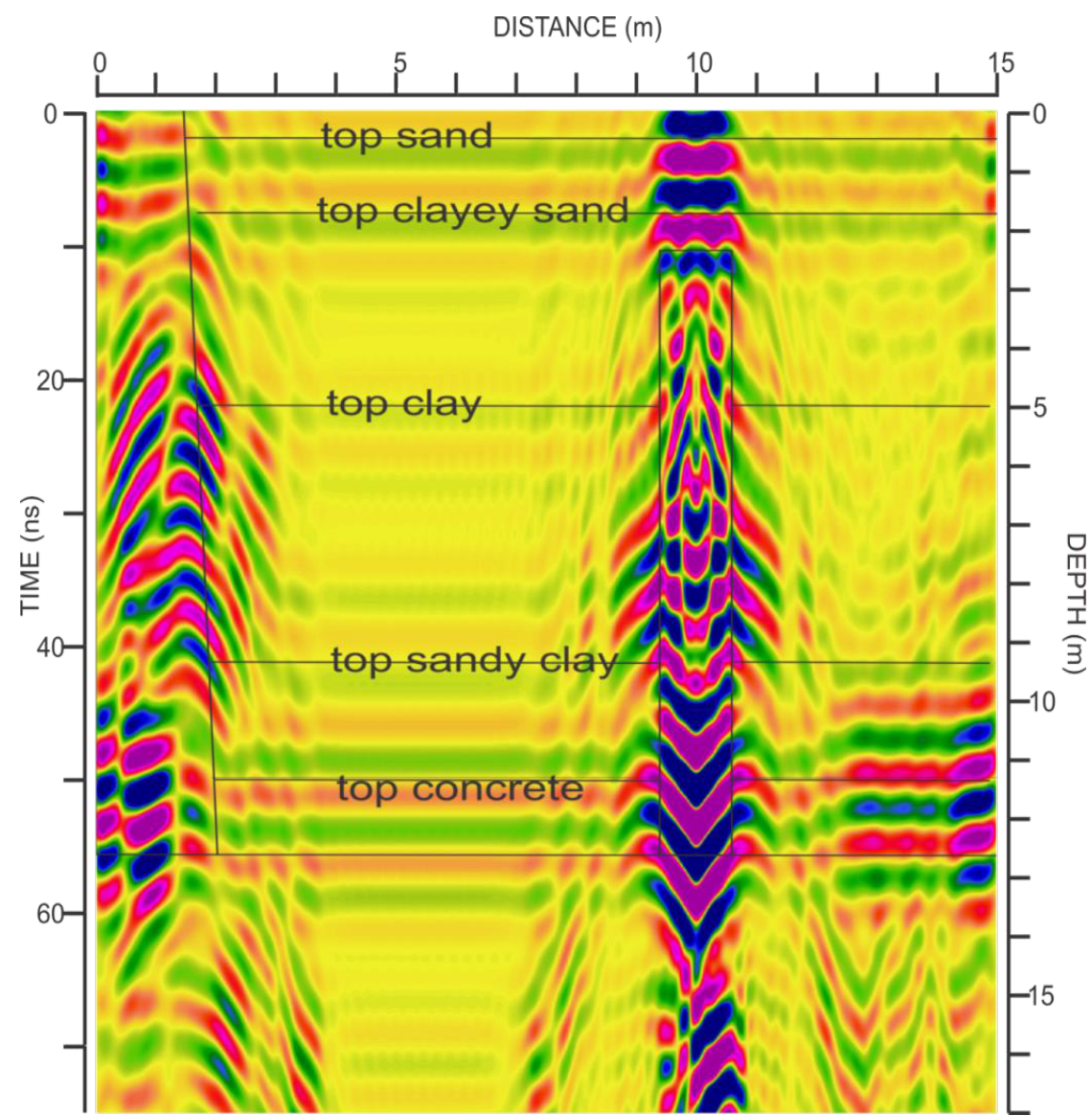

Figure 4. The radar image after interpretated by using synthetic model. 


\section{MAKALAH ILMIAH}

Here are the stages of the data proccessing that applied on the raw data image (Figure 5) to produce highresolution radar image.

\section{FIELD EXPERIMENT}

The synthetic model has been implemented to a field experiment. Electromagnetic wave data were acquired using GPR Zond 12C frequency $150 \mathrm{MHz}$ in Belawan Port, North Sumatra, KM 208, DMS coordinates $104^{\circ} 9^{\prime} 18^{\prime \prime} \mathrm{E}$ and 359'19" N (Figure 6) on February 2012.

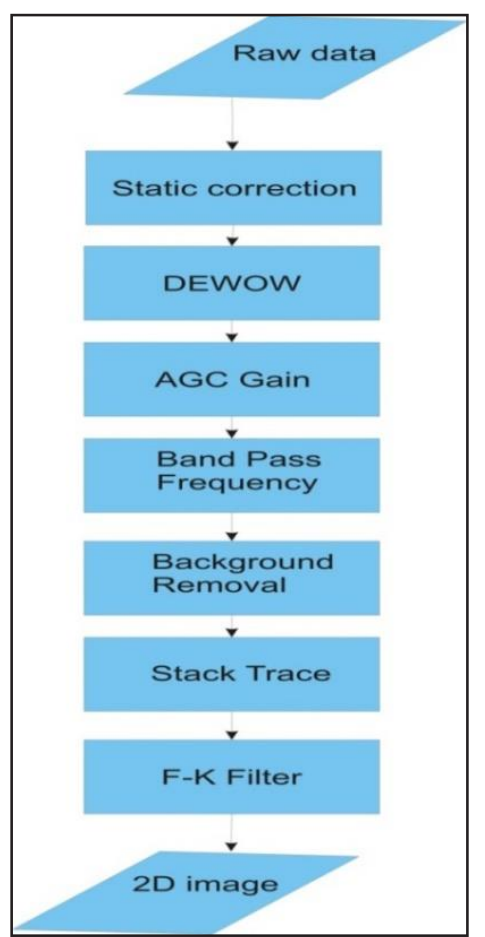

Figure 5. Flowchart of GPR data processing stages (Siregar, 2012).

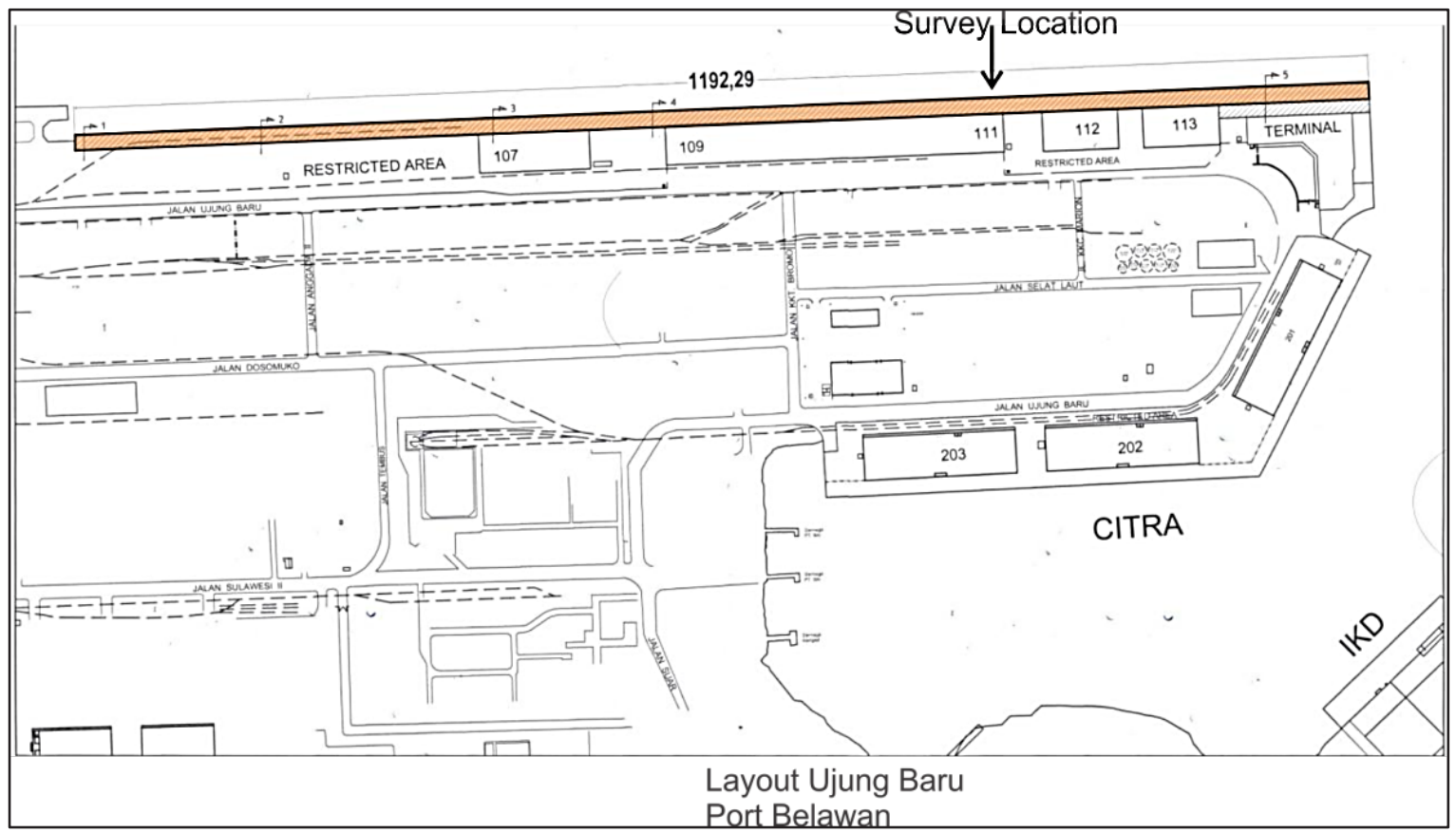

Figure 6. GPR survey location in Belawan (Siregar, 2012). 


\section{MAKALAH ILMIAH}

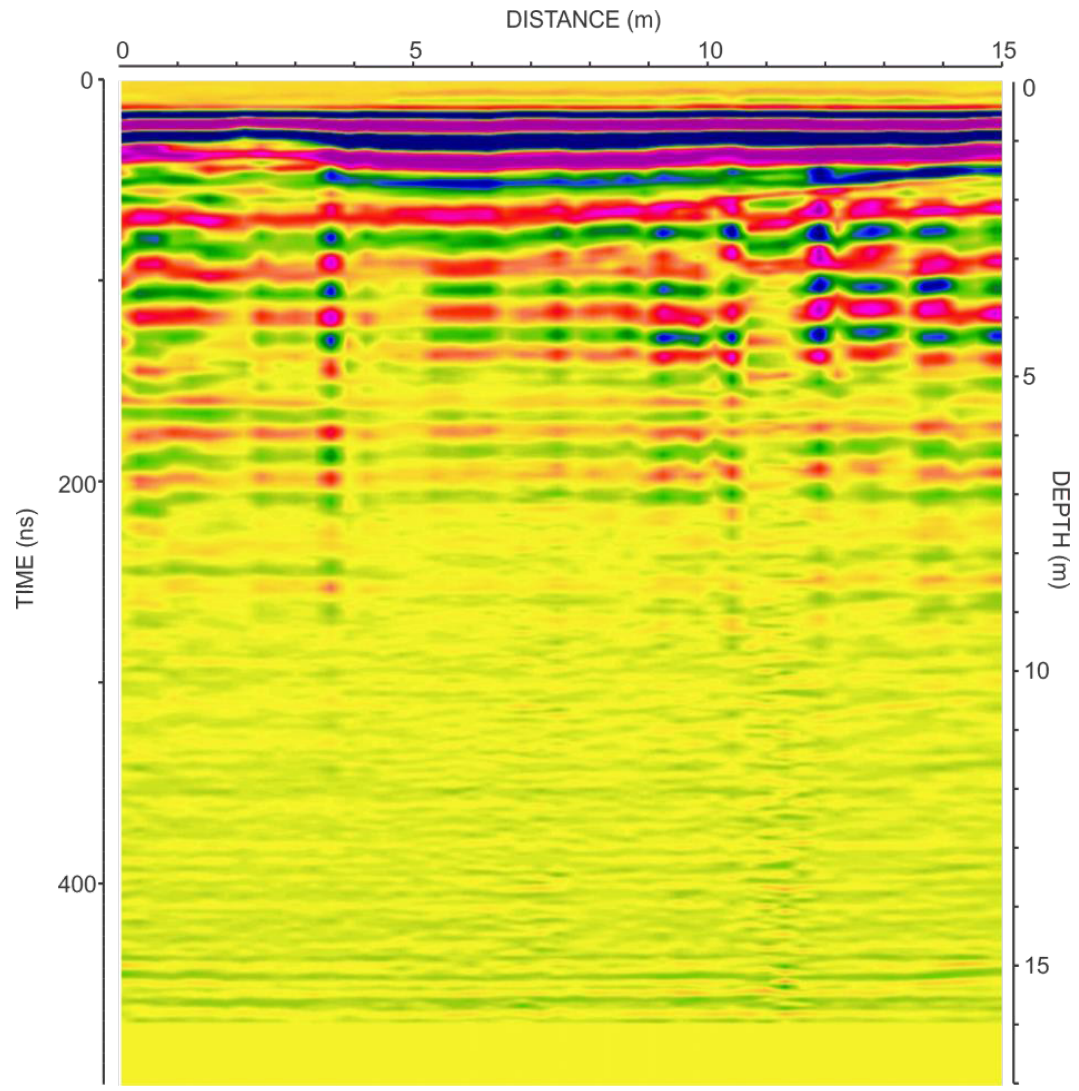

Figure 7. Raw data from the field experiment.

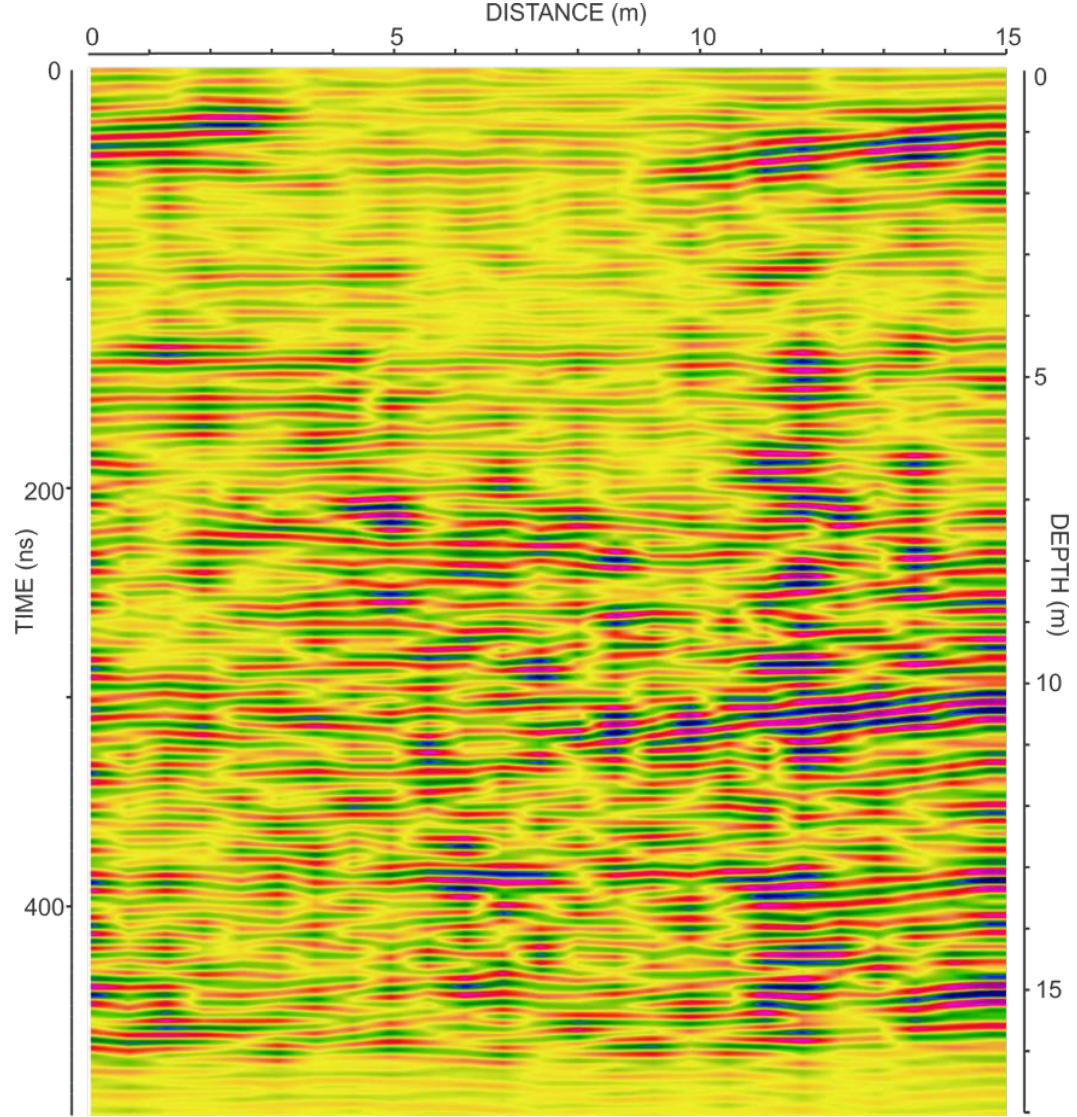

Figure 8. Processing result from the field experiment. 


\section{MAKALAH ILMIAH}

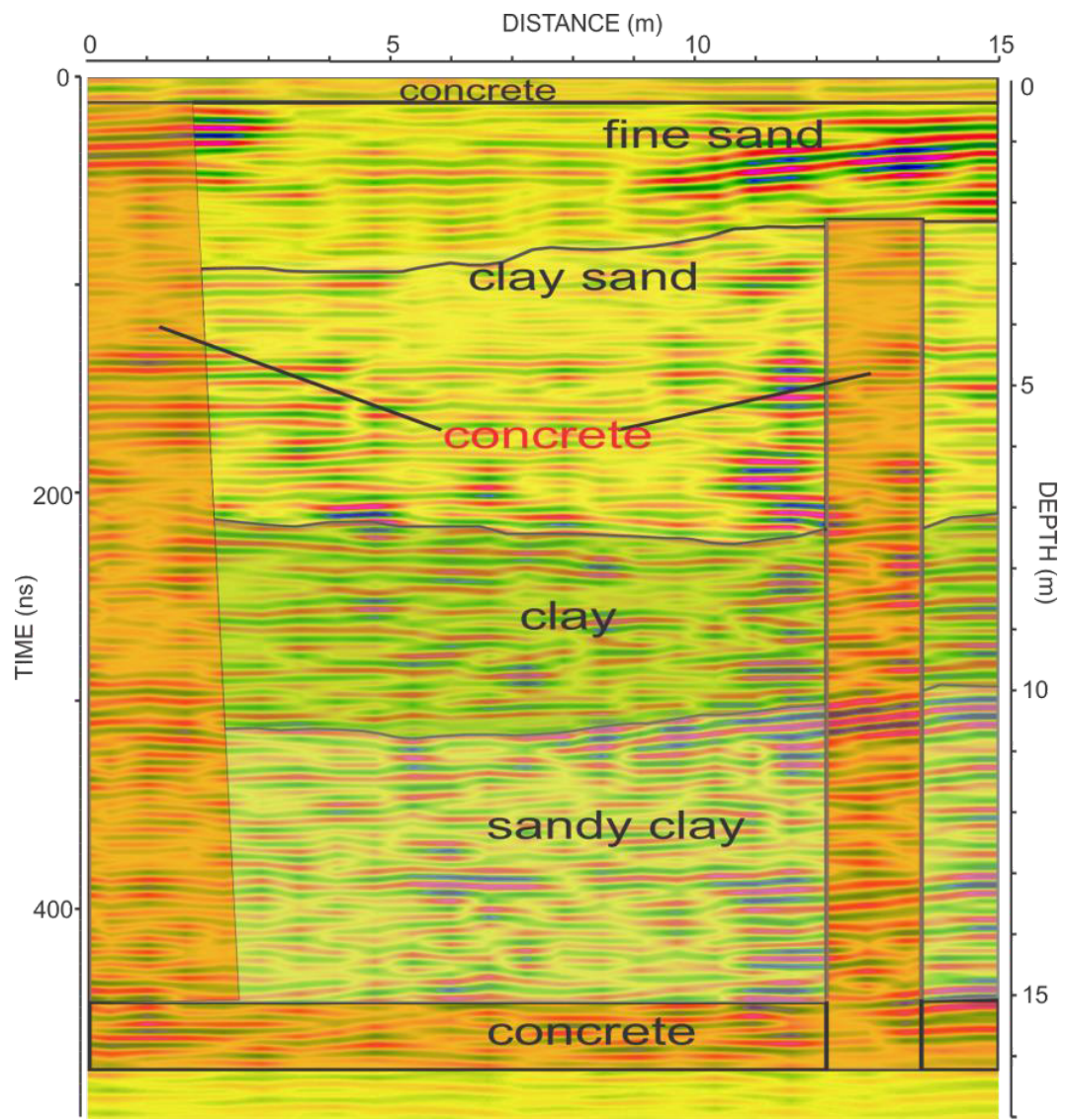

Figure 9. Interpretation result from the field experiment.

\section{DISCUSSION}

According to numerical simulation result, there are some advantages and disadvantages. The disadvantages are the numerical simulation requires relatively long simulations times and that structures may not be easily modelled (Buchanan, 1996). Naturally inhomogeneous media can only be represented by effective dielectric properties and placing small particles into a host medium never be statistically distributed (Müller, 2005). The advantages are it provides wide bandwith responses and can be used in parallel processing (Buchanan, 1996).

Electromagnetic radiation is combination of two fields which are electric field and magnetic field. Electric field properties of physical objects are controlled by electrical conductivity and permittivity meanwhile magnetic field properties are determined by permeability magnetic. Velocity and depth penetration are controlled by electrical permittivity whereas attenuation is determined by conductivity (Sulaiman and Taufik, 2010). Permeability magnetic shows response of atom and molecule toward magnetic field (Joll, 2001). Table 1 depicts that the dielectrical properties of the material are hardly contrast. The permittivity range from 3 to $30 \mathrm{~F} / \mathrm{m}$. Thus, the velocity range from 0,06 to $0,15 \mathrm{~m} / \mathrm{ns}$.

This study is limited to model without random noise characteristic. Moreover, the parameter in this study is generated with condition isotropy in horizontal and anisotropy in vertical (Figure 1). Generally, that is difficult to distinguish layer without any properties disparity. That can be explained by these equations:

$$
\begin{aligned}
& \mathrm{R}=\frac{\sqrt{\varepsilon_{2}}-\sqrt{\varepsilon_{1}}}{\sqrt{\varepsilon_{2}}+\sqrt{\varepsilon_{1}}} \\
& \mathrm{R}=\frac{\left(\mathrm{V}_{1}-\mathrm{V}_{2}\right)}{\left(\mathrm{V}_{1}+\mathrm{V}_{2}\right)}
\end{aligned}
$$

Where: 
$V_{1}, V_{2}=$ velocity in first layer and second layer

$\varepsilon_{1}, \varepsilon_{2}=$ dielectric constant in first layer and second layer

$R$ is reflectance coefficient. The higher $R$ the stronger the amplitude of signal. If the amplitude stronger than surrounded layer, we can delineate that become one boundary layer. We can find this phenomenon in raw data (Figure 2). There are some strong reflection and diffraction in the image. Those characteristics exist as a result of contrast impedance between adjacent object or layer.

For better understanding about the propagation of electromagnetic signal in the subsurface, the simple model of ray tracing is given below.

Fermat's principle states that light travel between two points along the path that requires the least time, as compared to other nearby paths. This principle is used as basic principle of wave propagation. The source and receiver position in Figure 10 are constant. From the Figure 10, we find that the raypath propagates through top of the concrete. It could explain about why only the response of concrete occur in the raw data.
In line with synthetic model in Figure 1, there shoud be a concrete, sand, clay, sandy clay and clayey sand responses in the image, however the response in the raw data is limited to concrete. Signal processing method should be applied to acquire information about these objects.

The steps of processing stages are shown

in Figure 5. With these steps, the signal is filtered and cut. After finishing processing stages, the interpretation data can be shown in Figure 4. The character of concrete responses are so clearly imaged. Other responses especially boundary layer can be identified but the response is not as clear as concrete.

From the shallow well data, the information about soil layer is gained and from the synthetic model, information about GPR signal characteristic, acquisition method, and processing technique are obtained. The raw data (Figure 7) from the field experiment processed by using processing stages in figure 5. From the processing result (Figure 8), some signal from raw data are cut and filtered in order to get better image.

\section{DISTANCE $(m)$}

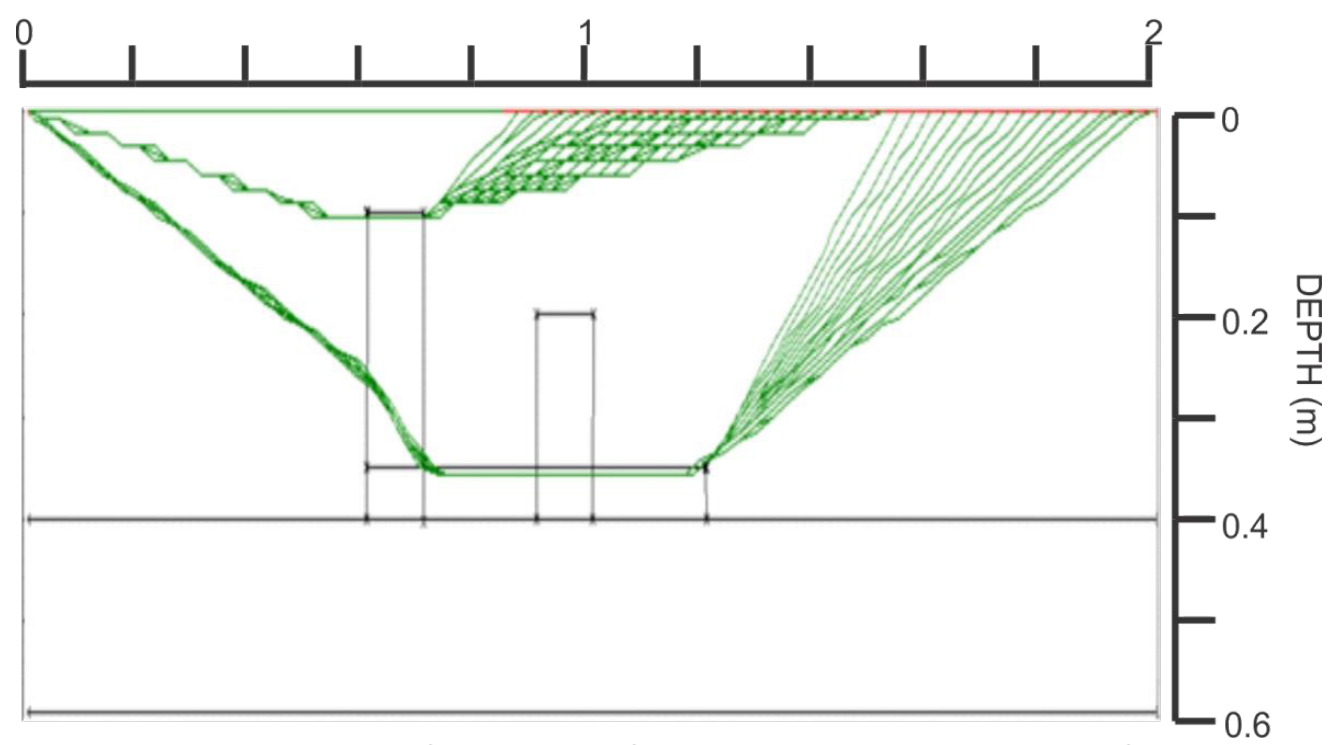

Figure 10. Various raypaths from the surface down to the individual reflecting horizons. 


\section{MAKALAH ILMIAH}

Interpretation in GPR (Figure 9) relies on five things, which are amplitude uniformity, wave velocity, signal continuity, wave characteristic, radar color index. Beside those, well to radar tie is very helpful to interpret radar data.

\section{CONCLUSIONS}

The result of this numerical simulation study of the electromagnetic data lead to the following conclusions:

Numerical simulation guides us to understand relationship between antenna frequency and depth penetration. Frequency: $150 \mathrm{MHz}$, sampling frequency: 900 Mhz, sample: 2500, time window: $2776.7 \mathrm{~ns}$, maximum depth: $17 \mathrm{~m}$, vertical resolution: 0.25 meter.

The characteristic of signal depends on the object beneath the surface. There are diffraction, reflection and cube wave in this study. The higher the reflectance coefficient the stronger the amplitude wave.

The processing stages in this study are: static correction, dewow, AGC gain, bandpass frequency, background removal, stack trace, and FK-filter.

\section{ACKNOWLEDGEMENT}

The author would like to thank all those who helped toward the entire process of drafting and publishing this study.

\section{REFERENCES}

Annan, A.P., 2003, Ground Penetrating Radar Principles, Procedures \& Applications. Sensors \& Software Inc., Canada, 278 h.
Annan, A.P. and Davis, 1989, Ground Penetrating Radar. Workshop Notes: Sensor \& Software Inc., Canada.

Baker, G. S. and Harry, 2007, Stratigraphic Analysis Using GPR: Geological Society of America.

Buchanan, W.J., 1996. Analysis of Electromagnetic Wave Propagation using the 3D Finite-Difference TimeDomain Method with Parallel Processing. Thesis for the degree of Doctor of Philosophy at Napier University, h. 1-12.

Joll, H.M., 2001, Ground penetrating radar: theory and application, Elsevier Publication.

McCann, et al., 1988, The Geology of Central Europe: The Geological Society.

Müller, K., 2005, Modelling of GPR Wave Propagation and Scattering in Inhomogeneous Media. Thesis for the degree of Master at University of Oslo, h. 13-16.

Reynold, J. M., 1997, An Introduction to Applied and Evironmental Geophysics : John Wiley \& Sons, Chicester, England.

Sandmeier, K. J., 1998, ReflexW Version 5 Reference manual.

Siregar, H.E.A., 2012. Identifikasi dan Analisis Pemodelan Fisik Pada Struktur Caisson Dermaga dan Struktur Beton Rumah Tinggal Dengan Menggunakan Metode Ground Penetrating Radar (GPR). Skripsi Sarjana di Program Studi Teknik Geofisika Fakultas Teknik Pertambangan dan Perminyakan Institut Teknologi Bandung, h. 31-33.

Sulaiman, A., dan Taufik, M., 2010, Pemodelan georadar 2D dengan metode beda hingga domain waktu. Jurnal Sains dan Teknologi Kebumian Indonesia,1, h. 31-41.

\begin{tabular}{|ll|}
\hline Diterima & $:$ 4 Februari 2016 \\
Direvisi & $:$ 23 Maret 2016 \\
Disetujui & $:$ 22 April 2016 \\
\hline
\end{tabular}

